\title{
Estimation and characterization of unintentionally produced persistent organic pollutant emission from converter steelmaking processes
}

\author{
Sumei Li • Minghui Zheng • Wenbin Liu • Guorui Liu • \\ Ke Xiao • Changliang Li
}

Received: 27 October 2013 / Accepted: 11 February 2014 / Published online: 1 March 2014

(C) Springer-Verlag Berlin Heidelberg 2014

\begin{abstract}
Unintentionally produced persistent organic pollutants (UP-POPs) including polychlorinated dibenzo- $p$-dioxins, and dibenzofurans (PCDD/Fs), polychlorinated biphenyls (PCBs), and polychlorinated naphthalenes (PCNs) were characterized and quantified in stack gas and fly ash from the second ventilation systems in five typical converters in five different steelmaking plants. The 2378-substituted PCDD/Fs (2378-PCDD/Fs) and dioxin-like PCB (dl-PCBs) toxic equivalents (TEQs) were 1.84-10.3 pg WHO-TEQ Nm ${ }^{-3}$ in the stack gas and 5.59-87.6 pg WHO-TEQ $\mathrm{g}^{-1}$ in the fly ash, and the PCN TEQs were $0.06-0.56 \mathrm{pg}^{-}$TEQ Nm${ }^{-3}$ in the stack gas and $0.03-0.08 \mathrm{pg} \mathrm{TEQ} \mathrm{g}^{-1}$ in the fly ash. The concentrations of UPPOPs in the present study were generally lower than those in other metallurgical processes, such as electric arc furnaces, iron ore sintering, and secondary metallurgical processes. Adding scrap metal might increase UP-POP emissions, indicating that raw material composition was a key influence on emissions. HxCDF, HpCDF, OCDF, HpCDD, and OCDD were the dominant $\mathrm{PCDD} / \mathrm{Fs}$ in the stack gas and fly ash. TeCB and $\mathrm{PeCB}$ were dominant in the stack gas, but $\mathrm{HxCB}$ provided more to the total PCB concentrations in the fly ash. The lower chlorinated PCNs were dominant in all of the samples. The 2378-PCDD/F, dl-PCB, and PCN emission factors in stack gases from the steelmaking converter processes (per ton of steel produced) were $1.88-2.89,0.14-0.76$, and 229-759 $\mathrm{g} \mathrm{t}^{-1}$, respectively.
\end{abstract}

Keywords UP-POPs $\cdot$ PCDD/Fs $\cdot$ PCBs $\cdot$ PCNs $\cdot$ Emission factor $\cdot$ Converter steelmaking

Responsible editor: Constantini Samara

S. Li $\cdot$ M. Zheng $(\bowtie) \cdot$ W. Liu $\cdot$ G. Liu $\cdot$ K. Xiao $\cdot$ C. Li State Key Laboratory of Environmental Chemistry and Ecotoxicology, Research Center for Eco-Environmental Sciences, Chinese Academy of Sciences, Beijing 100085, China

e-mail: zhengmh@rcees.ac.cn

\section{Introduction}

Polychlorinated dibenzo- $p$-dioxins and dibenzofurans (PCDD/Fs), polychlorinated biphenyls (PCBs), and polychlorinated naphthalenes (PCNs) are highly toxic, persistent in the environment, bioaccumulated through food webs, and can be transported on a global scale. PCDD/Fs, PCBs, and PCNs can be unintentionally produced in and emitted from thermal processes (such as incineration, electric arc furnaces (EAFs), iron ore sintering (SNT), and secondary metal smelting, so they are sometimes called unintentionally produced persistent organic pollutants (UP-POPs). The emission of UP-POPs from thermal industrial processes is currently of great interest and concern.

Metallurgical industries have been shown to be important sources of $\mathrm{PCDD} / \mathrm{F}$ emissions to the environment, and it has been reported that they are the most important PCDD/F sources (Anderson and Fisher 2002; Buekens et al. 2001). SNT and EAFs, used in integrated steelmaking processes, are thought to be two of the main global UP-POP sources (Aries et al. 2006; Liu et al. 2012a, b; Tian et al. 2012; Yu et al. 2012). UP-POP emissions from SNT have been found to be comparable to those from coking, but lower than those from thermal wire reclamation and copper secondary metallurgical processes (Hu et al. 2013a, b; Liu et al. 2009, 2012b; Nie et al. 2012a, b).

Compared with the number of studies of emissions from EAFs and SNT, there have been few studies of PCDD/F and PCB emissions from converter processes in steelmaking. No studies of PCN emissions from converter steelmaking plants have yet been carried out. The effects of certain factors that might be related to UP-POP emissions, such as the technologies applied, the converter scales, air pollution control technologies, and raw materials, were not throughout investigated in previous studies of $\mathrm{PCDD} / \mathrm{F}$ and $\mathrm{PCB}$ emissions during converter steelmaking (Fisher et al. 1997; Grochowalski et al. 
2006; Jackson et al. 2012). Therefore, more case studies are needed so that UP-POP emissions during converter steelmaking processes can be systematically and scientifically evaluated.

About half of the total global crude steel production is performed in China, where there are more than 600 converters of different types and sizes. It is, therefore, important to study the converter steelmaking processes used in China to improve our knowledge of UP-POP emissions from these plants. In this study, UP-POP emissions from five converters in five different steelmaking plants in northern China were studied. The relationships between different UP-POP concentrations in the samples were examined to identify similarities between different chemicals. The main factors that influenced UP-POP emissions were assessed, and the UP-POP emissions from the converter steelmaking processes were characterized. The results will be useful for developing and implementing control measures for UP-POP emissions from converter steelmaking processes.

\section{Materials and methods}

Sampling procedures

Converter steelmaking processes normally have three stages: desulfurization, decarburization, and secondary metallurgical processes. Molten iron, scrap steel, iron alloys, and other materials are used as the primary raw materials. The molten iron is converted into liquid steel in the converter, and this process does not require extra energy resources, simply using the heat $\left(>1,200^{\circ} \mathrm{C}\right)$ already present and produced by chemical reactions involving the molten iron itself to make the steel. Typically, an average of $10-30 \%$ of the converter charge is scrap steel, which is used as a kind of coolant.

Most of the gases and particles are generated during the blowing, charging, and tapping steps in the steelmaking process. A secondary ventilation system is installed directly above the converters, and this usually consists of a roofmounted canopy hood designed to capture the particles.
However, not all of the particles can be captured. So there is a potential risk for workers to be exposed to particulates and chemicals.

Top- and bottom-blown converters are the most popular techniques for steelmaking. In this study, one top-blown converter (C5) and four top- and bottom-blown converters (C1C4) from five different steelmaking plants were investigated. The sizes of the converters studied ranged from 50 to $300 \mathrm{t}$ (per batch). A more modern steelmaking technique was used in converter $\mathrm{C} 1$, which produces a higher-quality steel, used less energy, and emitted less common pollutants. This modern technique involved the molten iron being desulfurized in a desulfurization station, and dephosphorized and desiliconized in a converter, to decrease its sulfur, phosphorus, and silicon contents, before being decarburized. The molten iron pretreatment in the other four converters only involved a desulfurization step in a desulfurization station and a dephosphorization step in a ladle or a torpedo car before decarburization.

A total of 15 stack gas and five fly ash samples were collected from the secondary ventilation systems of the five converters. Secondary ventilation systems primarily capture gases and particles produced during the charging and tapping processes. The air pollution control devices (APCDs) used in the converters studied were bag filters. The stack gas sampling points were located downstream of the APCDs. The temperature of the stack gas after bag filters were in the range of 50 $70{ }^{\circ} \mathrm{C}$. The stack gas samples were collected using an automatic isokinetic sampling system (Isostack Basic; TCR TECORA, Milan, Italy). Three stack gas samples were collected from each plant to investigate UP-POP emissions. Details of the converter steelmaking plants are shown in Table 1.

Preparation and analysis of samples

PCDD/Fs, PCBs, and PCNs were quantified using isotope dilution high-resolution gas chromatography-high-resolution mass spectrometry (MS) methods. The PCDD/Fs and PCBs were analyzed using method EN $1948(\mathrm{PCDD} / \mathrm{Fs})$ and EPA 1668B (PCBs). The stack gas samples were spiked with

Table 1 Basic information on the converter steelmaking plants studied

\begin{tabular}{|c|c|c|c|c|c|}
\hline & $\mathrm{C} 1$ & $\mathrm{C} 2$ & $\mathrm{C} 3$ & $\mathrm{C} 4$ & $\mathrm{C} 5$ \\
\hline Converter type & $\mathrm{TB}^{\mathrm{a}}$ & $\mathrm{TB}^{\mathrm{a}}$ & $\mathrm{TB}^{\mathrm{a}}$ & $\mathrm{TB}^{\mathrm{a}}$ & $\mathrm{T}^{\mathrm{b}}$ \\
\hline Converter scale (tons) & 300 & 120 & 120 & 120 & 50 \\
\hline Percentage of scrap steel added (\%) & 20 & 16 & 15 & 12 & 10 \\
\hline Air pollution control device & Bag filters & Bag filters & Bag filters & Bag filters & Bag filters \\
\hline Average stack gas flow rate (Newton cubic meter per hour) & 324,279 & $1,175,206$ & 994,669 & 543,129 & 199,229 \\
\hline Fly ash production rate (tons per year) & 2580 & 3192 & 1440 & 732 & 516 \\
\hline
\end{tabular}

${ }^{\mathrm{a}}$ Top- and bottom-blown converter

b Top-blown converter 
Table 2 UP-POP concentrations in stack gas and fly ash from the converter steelmaking processes

\begin{tabular}{|c|c|c|c|c|c|c|c|c|c|c|}
\hline \multirow[t]{2}{*}{ Compound } & \multicolumn{2}{|l|}{$\mathrm{C} 1$} & \multicolumn{2}{|l|}{$\mathrm{C} 2$} & \multicolumn{2}{|l|}{$\mathrm{C} 3$} & \multicolumn{2}{|l|}{$\mathrm{C} 4$} & \multicolumn{2}{|l|}{$\mathrm{C} 5$} \\
\hline & Gas $(n=3)$ & Ash & $\operatorname{Gas}(n=3)$ & Ash & $\operatorname{Gas}(n=3)$ & Ash & $\operatorname{Gas}(n=3)$ & Ash & Gas $(n=3)$ & Ash \\
\hline $\begin{array}{l}\sum 2378 \text {-chlorinated } \mathrm{PCDD} / \mathrm{Fs} \text { (picogram Newton } \\
\text { per cubic meter or picogram per gram) }\end{array}$ & $76.0-104$ & 2.26 & $44.7-123$ & 2.87 & $62.9-163$ & 0.14 & $75.1-159$ & 0.14 & $81.2-124$ & 0.24 \\
\hline $\begin{array}{l}\sum \text { dl-PCBs (picogram Newton per cubic meter } \\
\text { or picogram per gram) }\end{array}$ & $529-747$ & 0.005 & $52.7-224$ & 0.07 & $44.7-91.9$ & 0.18 & $57.0-199$ & 0.09 & $35.8-66.4$ & 0.07 \\
\hline $\begin{array}{l}\sum \text { PCNs (nanogram Newton per cubic meter or } \\
\text { nanogram per gram) }\end{array}$ & $11.2-40.8$ & 2.94 & $18.0-44.3$ & 2.00 & $1.49-5.64$ & 2.71 & $3.38-9.29$ & 2.52 & $5.43-11.1$ & 1.80 \\
\hline $\begin{array}{l}\text { WHO-TEQ (picogram TEQ Newton per cubic } \\
\text { meter or picogram TEQ per gram) }\end{array}$ & $5.47-10.3$ & 87.6 & $1.84-4.64$ & 57.8 & $6.07-10.0$ & 5.59 & $3.07-5.37$ & 8.83 & $3.37-4.36$ & 13.3 \\
\hline $\begin{array}{l}\text { TEQ of PCNs (picogram TEQ Newton per cubic } \\
\text { meter or picogram TEQ per gram) }\end{array}$ & $0.41-0.56$ & 0.08 & $0.19-0.22$ & 0.03 & $0.07-0.26$ & 0.04 & $0.08-0.27$ & 0.06 & $0.06-0.23$ & 0.07 \\
\hline
\end{tabular}

${ }^{13} \mathrm{C}_{12}$-labeled internal standards and then extracted with toluene for about $24 \mathrm{~h}$ in a Soxhlet apparatus. After eluting the extracts through multilayer silica gel columns and activated carbon columns, they were concentrated to about $20 \mu \mathrm{l}$. Before injection, ${ }^{13} \mathrm{C}_{12}$-labeled injection standards were added so that the recoveries of the internal standards could be calculated. The fly ash samples were spiked with ${ }^{13} \mathrm{C}_{12}$-labeled internal standards and pretreated with $1 \mathrm{~mol} \mathrm{l}^{-1} \mathrm{HCl}$ before being extracted. The extraction and cleanup methods were the same for the fly ash samples as for the stack gas samples. The same extraction and cleanup procedures were used for the PCNs as were used for the PCBs, for both the stack gas and fly ash samples.

$\mathrm{PCDD} / \mathrm{Fs}, \mathrm{PCBs}$, and PCNs were analyzed in the extracts using an Agilent 6890 gas chromatograph coupled with a Waters Autospec Ultima high-resolution MS. A DB-5 MS fused-silica column $(60 \mathrm{~m} \times 0.25 \mathrm{~mm}$ i.d. $\times 0.25 \mu \mathrm{m})$ was used to separate the analytes. The MS was calibrated using perfluorokerosene, and it was operated at $\geq 10,000$ resolution with an electron impact ionization source set at an electron energy of $38 \mathrm{eV}$.

Quality control and quality assurance

The recoveries of the surrogate sampling standards in the stack gas samples were $75-105 \%$, and they met the analytical method requirements. The ${ }^{13} \mathrm{C}_{12}$-labeled $\mathrm{PCDD} / \mathrm{F}, \mathrm{PCB}$, and $\mathrm{PCN}$ internal standard recoveries were $45-119 \%, 50-126 \%$, and 53-121\%, respectively, proving the validity of the analytical methods used. A target compound was identified if the GC retention time of the peak of interest matched the corresponding ${ }^{13} \mathrm{C}_{12}$-labeled standard, the signal-to-noise ratio was greater than $3: 1$, and the isotopic ratio between the quantitation and confirmation ions was within $\pm 15 \%$ of the theoretical value. One blank sample was included in each batch of samples analyzed, and only OCDD and OCDF concentrations were a little higher than detection limits, but were lower than the $10 \%$ of the concentration in the stack gas and fly ash.

The UP-POP concentrations in the stack gas were converted to "dry standard conditions" (273 K and $101.3 \mathrm{kPa}$ ) and the 2005 World Health Organization (WHO) authorized toxic equivalence factors (TEFs) that were used to calculate the $\mathrm{PCDD} / \mathrm{F}$ and dl-PCB toxic equivalents (TEQs). The PCN TEQ was defined as the sum of the products of the concentration of each PCN congener multiplied by the potency factors (RPF) of PCN congeners relative to 2378-tetrachlorodibenzo-
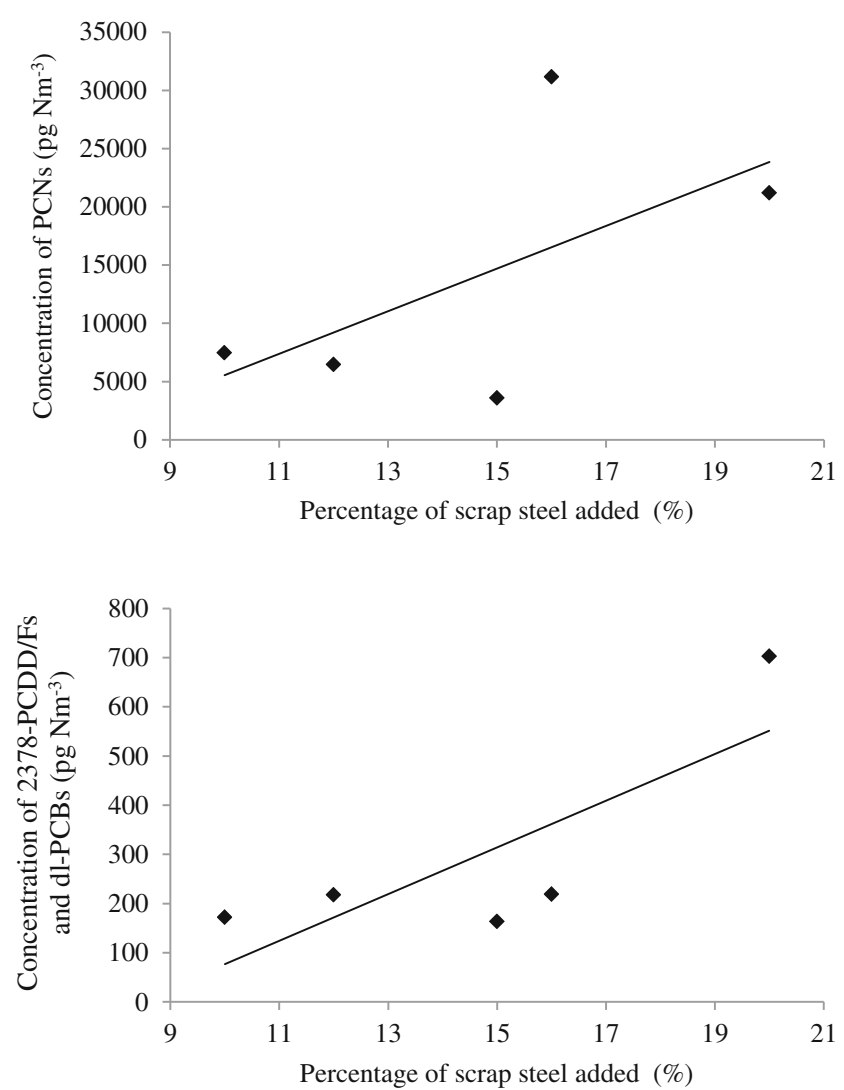

Fig. 1 Relationships between the percentage of scrap steel added and the unintentionally produced persistent organic pollutant concentrations in the stack gas 
$p$-dioxin (Noma et al. 2004). For congeners found at concentrations below the limit of detection (LOD), a value of half of the LOD was used to calculate the total concentrations and the TEQs.

\section{Results and discussion}

UP-POP concentrations emitted by the converter steelmaking processes

The PCDD/F, PCB, and PCN concentrations and their TEQs are summarized in Table 2. The 2378-substituted PCDD/F concentrations in the stack gas were $0.045-0.16 \mathrm{ng} \mathrm{Nm}^{-3}$ (0.77-12.9 pg WHO-TEQ $\mathrm{Nm}^{-3}$ ), which were similar to the concentrations (1-13 and $17.7 \mathrm{pg} \mathrm{I-TEQ} \mathrm{Nm}^{-3}$ ) found in other converter steelmaking plant stack gas (Fisher et al. 1997; Grochowalski et al. 2006). The PCDD/F concentrations in the fly ash were $0.14-2.26 \mathrm{ng} \mathrm{g}^{-1}$ (5.52-87.6 $\mathrm{pg}$ WHO-TEQ $\mathrm{g}^{-1}$ ), which were much lower than those found in EAFs (Chiu et al. 2011; Jager 1993; Sofilic et al. 2012).

The dl-PCB concentrations were $0.036-0.75 \mathrm{ng} \mathrm{Nm}^{-3}$ $\left(0.03-2.85 \mathrm{pg}\right.$ WHO-TEQ $\left.\mathrm{Nm}^{-3}\right)$ in the stack gas and

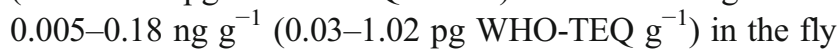
ash. These results are similar to the dl-PCB concentrations found in basic oxygen furnaces and EAFs (Grochowalski

b

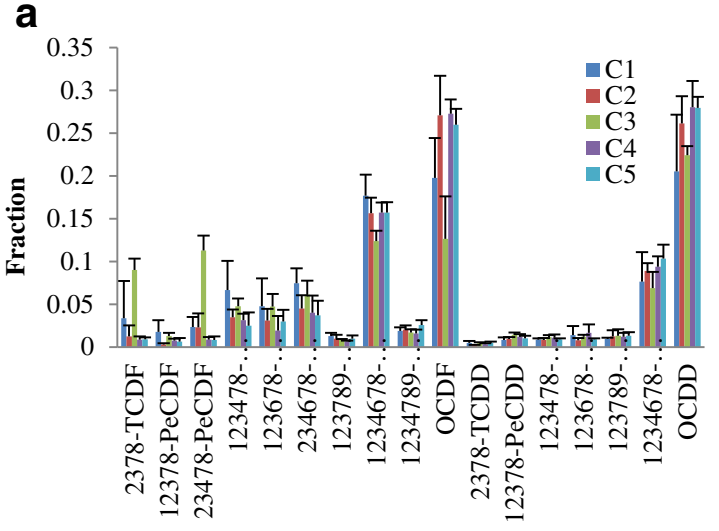

a
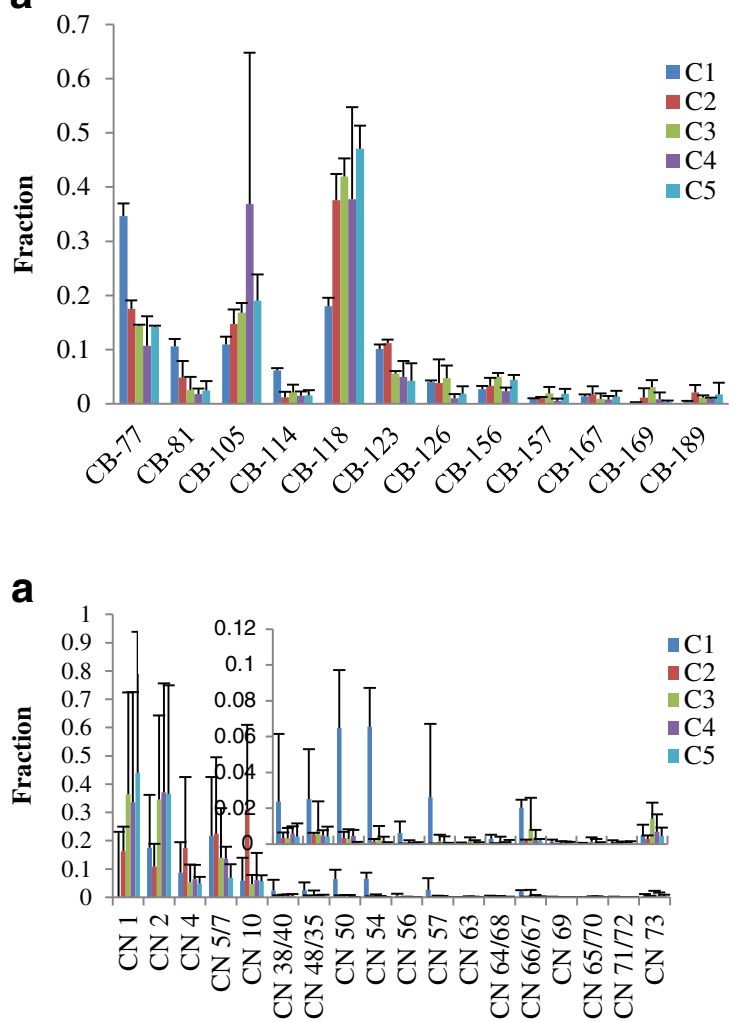

b

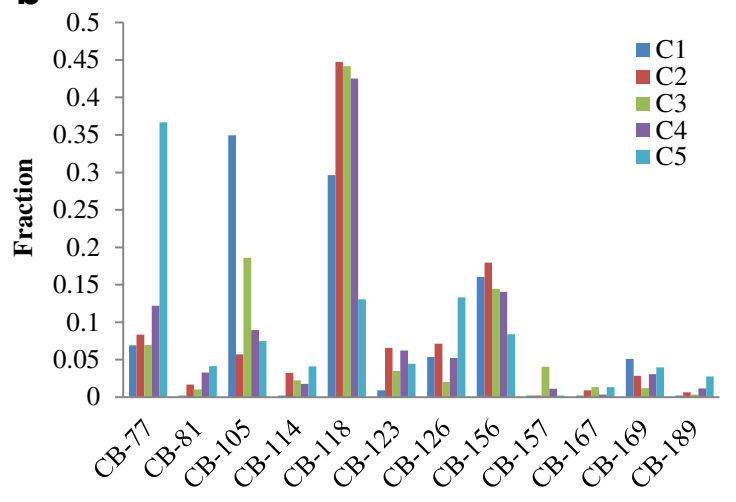

b
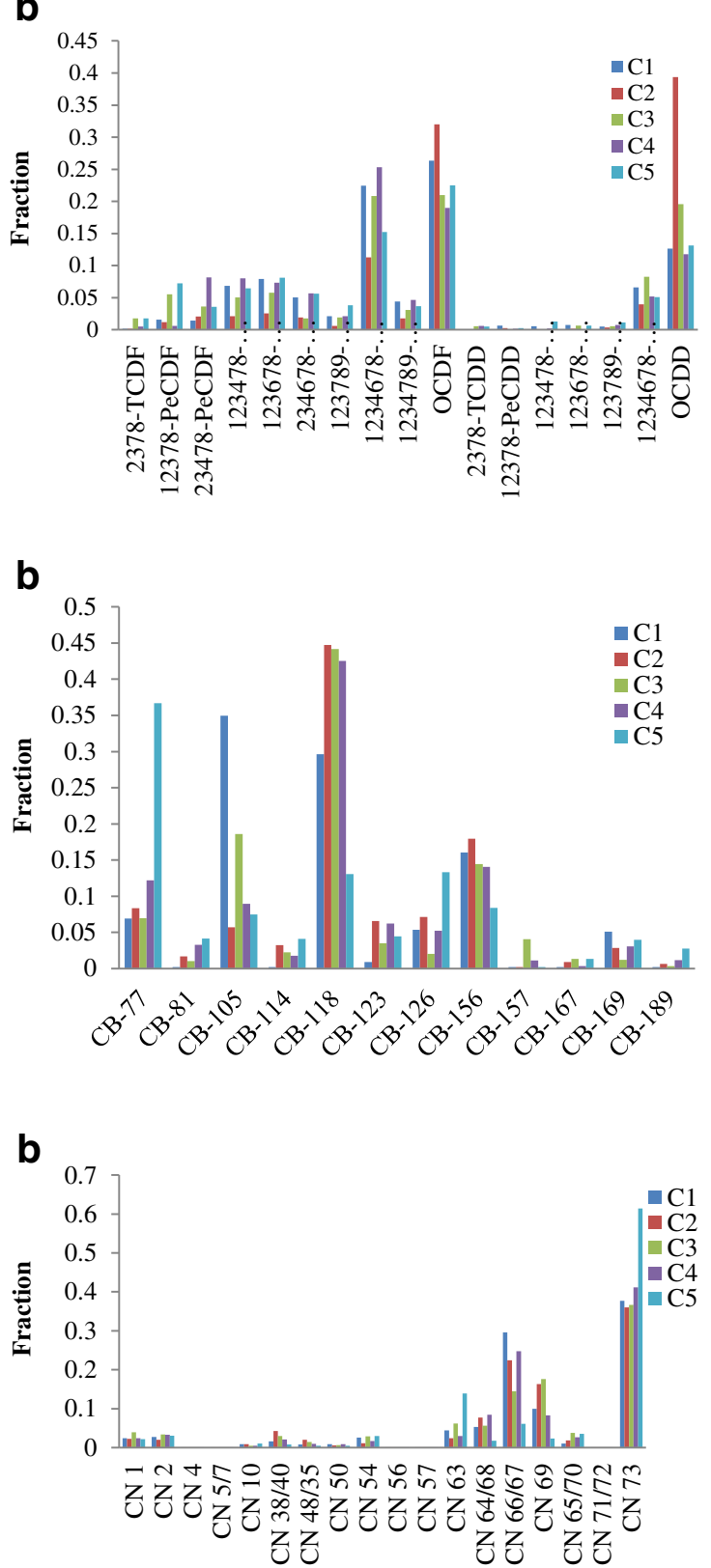

Fig. 2 PCDD/F, dl-PCB, and PCN fingerprints for the (a) stack gas and (b) fly ash from the converter steelmaking processes 
et al. 2006) in Poland, but much lower than dl-PCBs emissions found in SNT plants in the UK, which were 42-111 pg WHO-TEQ Nm${ }^{-3}$ (Aries et al. 2006).

The average PCN concentrations in the stack gas and fly ash were $20.9 \mathrm{ng} \mathrm{Nm}^{-3}$ (range 3.38-44.3 $\mathrm{ng} \mathrm{Nm}^{-3}$ ) and $2.39 \mathrm{ng} \mathrm{g}^{-1}$ (range $1.80-2.94 \mathrm{ng} \mathrm{g}^{-1}$ ), respectively. The mean PCN TEQs in the stack gas and fly ash were 0.23 pg TEQ $\mathrm{Nm}^{-3}\left(0.06-0.56 \mathrm{pg}^{\mathrm{T}} \mathrm{TEQ} \mathrm{Nm}^{-3}\right)$ and $0.06 \mathrm{pg}^{\mathrm{TEQ}} \mathrm{g}^{-1}(0.03-$ $\left.0.08 \mathrm{pg}^{\mathrm{TEQ}} \mathrm{g}^{-1}\right)$, respectively. PCN emissions from converter steelmaking processes have not been reported before. The PCN concentrations were much lower than those have been found in stack gases produced by other thermal processes, such as secondary metal smelting (41.3-8,021 $\left.\mathrm{ng} \mathrm{Nm}^{-3}\right)$, SNT (3-983 $\mathrm{ng} \mathrm{Nm}^{-3}$ ), thermal wire reclamation $(2,045-$ $\left.14,490 \mathrm{ng} \mathrm{Nm}^{-3}\right)$, and magnesium metallurgical $(2,470-$ 93,400 $\mathrm{ng} \mathrm{Nm}^{-3}$ ) processes (Ba et al. 2010; Liu et al. 2010, 2012b; Nie et al. 2011, 2012b).

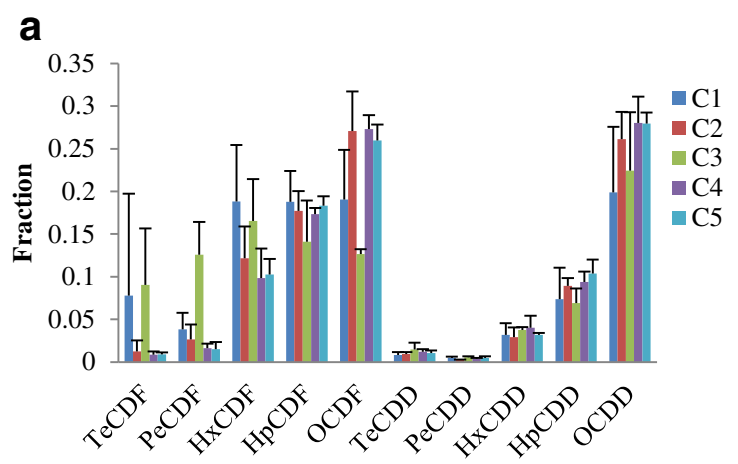

a

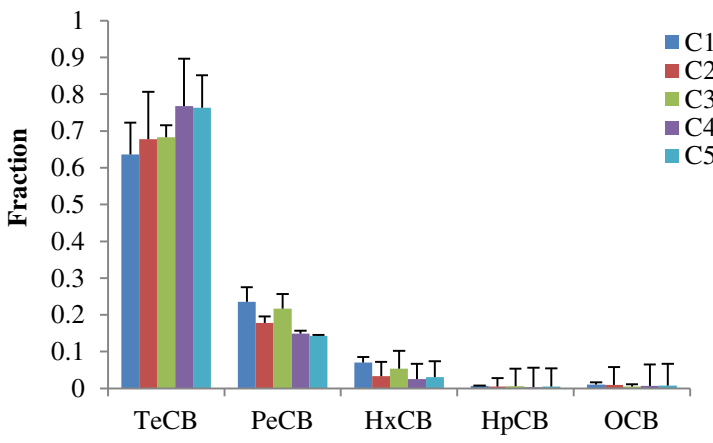

a

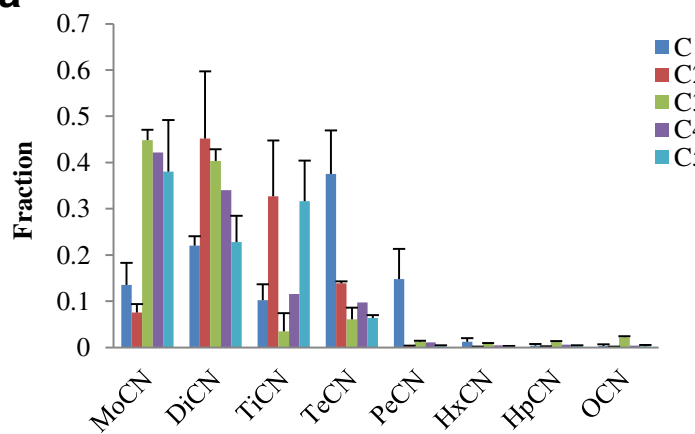

The UP-POP emissions from plant $\mathrm{C} 1$ were in the same range as those from plants $\mathrm{C} 2-\mathrm{C} 5$. This indicates that the modern steelmaking techniques used in plant $\mathrm{C} 1$, to produce high-quality steel, to save energy, and to reduce emissions of common pollutants, were not likely to help decrease UP-POP emissions. We also assessed other factors affecting UP-POP emissions and found that the amount of scrap metal added might affect the UP-POP concentrations in the stack gas. The preliminary results in Fig. 1 shows the increase in the UP-POP concentrations in the stack gas with increasing amount of scrap steel added, especially for 2378-PCDD/Fs and dlPCBs. Further study with much more case plants is needed for establishing the correlations between raw materials and UP-POP emissions.

Some scrap steel may contain oil, surface oxidation, and chlorinated organic chemicals. The preliminary heating of the iron and scrap steel takes place in the presence of plastics,

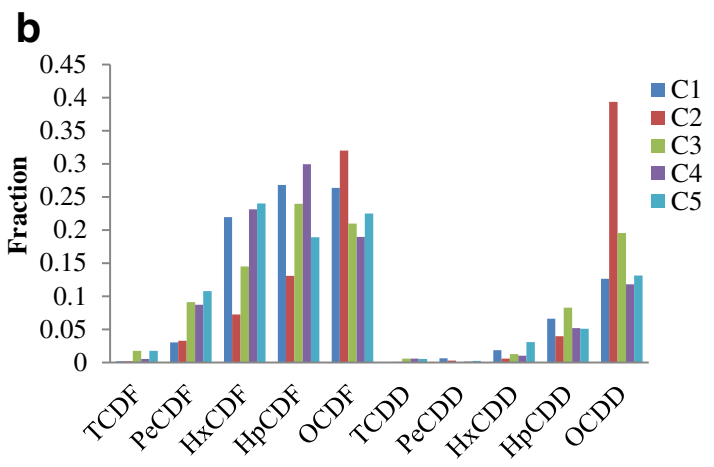

b

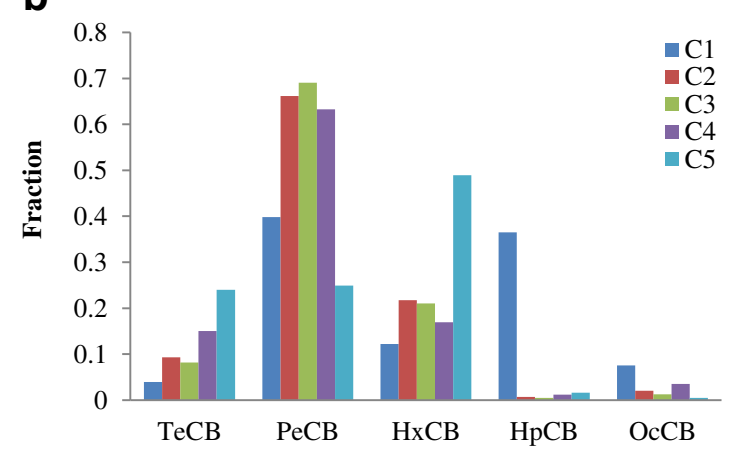

b

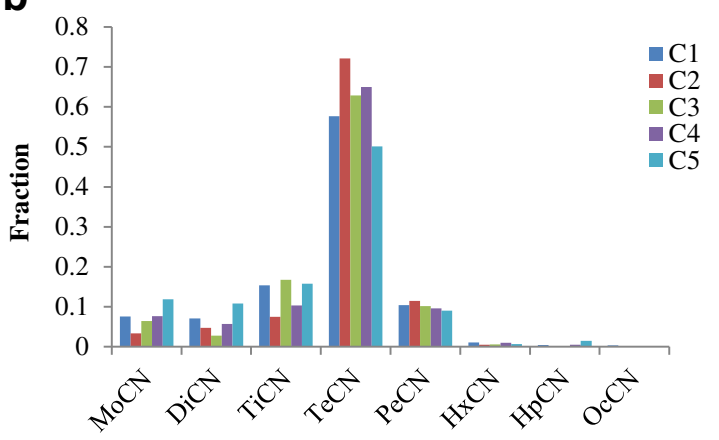

Fig. 3 PCDD/F, dl-PCB and PCN homolog profiles in the (a) stack gas and (b) fly ash from the converter steelmaking processes 
coatings, paint, seals, and nonferrous metals (Grochowalski et al. 2006). Therefore, the addition of scrap steel might be an important source of chlorine that may lead to the formation of UP-POPs. The pretreatment of scrap metal to remove these unwanted impurities should be thus helpful in decreasing the UP-POP emissions from converter steelmaking processes.

\section{Characteristics of the UP-POPs emissions}

The homolog profiles for the 17 2378-substituted PCDD/Fs (2378-PCDD/Fs), 12 dl-PCBs, and 18 dl-PCNs (i.e., PCN congeners with RPFs) were used to form fingerprints of the $\mathrm{PCDD} / \mathrm{F}$, dl-PCB, and PCN emissions from the converter steelmaking plants. The PCDD/F, dl-PCB, and dl-PCN concentrations were normalized to the total $2378-\mathrm{PCDD} / \mathrm{F}$, total dl-PCB, and total PCN concentrations, respectively, to illustrate the PCDD/F, dl-PCB, and PCN distributions in the stack gas and fly ash from the converter steelmaking plants.

The 2378-PCDD/F, dl-PCB, and dl-PCN fingerprints in the stack gas and fly ash are shown in Fig. 2. Similar 2378-PCDD/ $\mathrm{F}$ fingerprints were found in all five converter steelmaking plants. 1234678-HpCDF, 1234678-HpCDF, OCDD and OCDF were the main PCDD/F congeners in the stack gas and fly ash. CB-77, 105, and 118 were the main dl-PCB congeners in the stack gas and fly ash, CB-118 being the most abundant. Lower chlorinated PCN congeners, such as $\mathrm{CN}-1$, $\mathrm{CN}-2$, and $\mathrm{CN}-5 / 7$, were the main PCNs in the stack gas. Higher chlorinated PCN congeners, such as CN-73, CN-66/
67, and CN-79, contributed a larger proportion of the total PCNs in the fly ash. It would have been, at least partly, caused by the fraction of semivolatile compounds adsorbed to particles being higher for less volatile congeners (Lohmann and Jones 1998). The 2378-PCDD/F, dl-PCB, and dl-PCN fingerprints in the converter steelmaking process were very similar to fingerprints found in other thermal processes including SNT, secondary copper smelting, and EAF processes $(\mathrm{Hu}$ et al. 2013a; Liu et al. 2012a, b).

The PCDD/F, dl-PCB, and PCN homolog profiles in the stack gas and fly ash from the converter steelmaking processes are shown in Fig. 3. The higher chlorinated PCDD/F homologs, such as the HxCDF, HpCDF, OCDF, HpCDD and OCDD, were the main PCDD/F homologs in all of the stack gas and fly ash. The lower chlorinated PCBs, such as the $\mathrm{TeCB}$ and $\mathrm{PeCB}$, were the dominant PCBs in the stack gas, but the higher chlorinated PCBs (e.g., the $\mathrm{HxCB}$ ) were found at higher proportions of the total $\mathrm{PCB}$ concentrations in the fly ash. The lower chlorinated PCNs (MoCN, DiCN, TiCN, and $\mathrm{TeCN}$ ) were dominant in all 15 of the stack gas, accounting for more than $80 \%$ of the total PCN concentrations. However, the $\mathrm{PeCN}$ were found at much higher concentrations in the stack gas from plant $\mathrm{C} 1$ than in the stack gas from the other plants. The TiCN, TeCN, and PeCN were the main homologs found in the fly ash, accounting for more than $75 \%$ of the total PCN concentrations.

Based on the target compound concentrations, principal component analysis (PCA) was performed and the results are shown
Fig. 4 Plot of the first and second principal components of the target compound concentrations

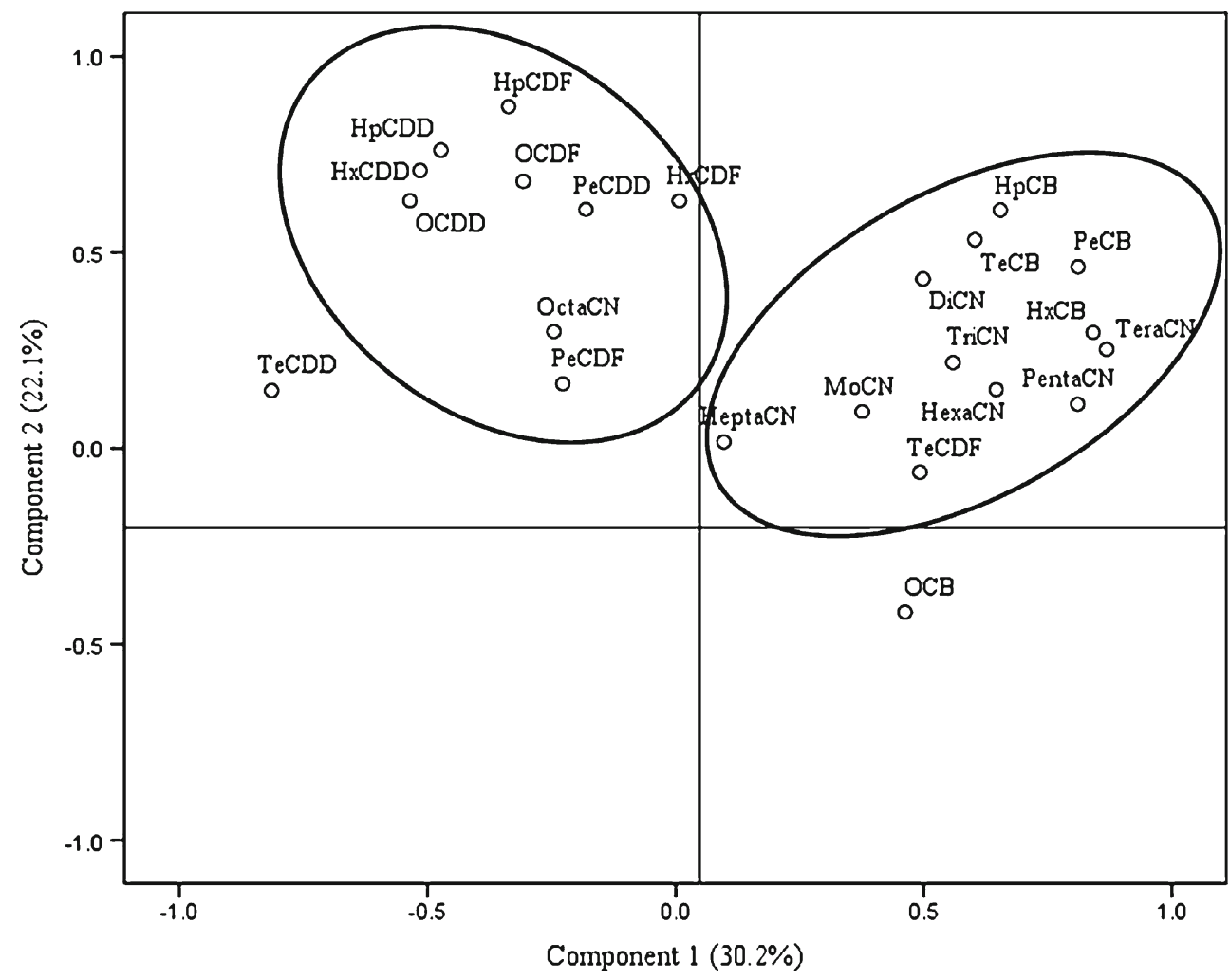


in Fig. 4. The PCA analysis showed that the PCN concentrations were closely related to the PCB concentrations in the stack gas. Most of the PCB and PCN homolog concentrations are in the upper right part of Fig. 4, while most of the PCDDs and PCDFs are located in the upper left part of the figure.

Figure 5 shows that the sum of the tetra- to octa-chlorinated PCB concentrations generally correlated well with the sum of the tetra- to octa-chlorinated PCN concentrations $\left(r^{2}=0.74\right)$. This shows that the PCBs might have similar formation pathways to the PCNs in the converter steelmaking processes.

Estimating UP-POPs emissions from the converter steelmaking processes

Emission factors are generally used to estimate the total emissions of a given pollutant from a given source, based on limited data. Emission factors need to be determined to estimate UP-POP emission inventories and to assist regulatory agencies in developing appropriate control strategies so that overall emissions can be caused to decrease. Emission factors and amounts emitted were calculated for each of the chemicals analyzed in this study using the equations we have presented previously (Liu et al. 2012b; Nie et al. 2011, 2012a).

The 2378-PCDD/F, dl-PCB, and PCN stack gas emission factors (per ton of steel produced) for the converter steelmaking processes were 1.88-2.89 $\mathrm{\mu g} \mathrm{t}^{-1}(5.38-50.7 \mathrm{ng}$ WHO$\left.\mathrm{TEQ}_{\mathrm{PCDD} / \mathrm{Fs}} \mathrm{t}^{-1}\right), 0.14-0.76 \mu \mathrm{g} \mathrm{t}^{-1}(0.26-3.45 \mathrm{ng}$ WHO$\left.\mathrm{TEQ}_{\mathrm{dl}-\mathrm{PCBs}} \mathrm{t}^{-1}\right)$, and 229-759 $\mu \mathrm{g} \mathrm{t}^{-1}\left(0.32-1.54 \mathrm{ng}^{\mathrm{T}}\right.$ TEQ $\left.\mathrm{t}^{-1}\right)$, respectively. The PCDD/F emission factors were comparable to emission factors that have been reported previously (Grochowalski et al. 2006), but much lower than emission factors proposed by the UNEP toolkit (UNEP 2012, Stockholm Convention) for converter steelmaking with clean raw materials $\left(0.1 \mu \mathrm{g} \mathrm{TEQ}^{-1}\right)$. The 2378-PCDD/F, dl-PCB, and PCN fly ash emission factors were $0.11-6.70,0.06-0.18$ and 2.19-18.9 $\mathrm{M} \mathrm{t}^{-1}$, respectively. Nearly all of the fly ash produced

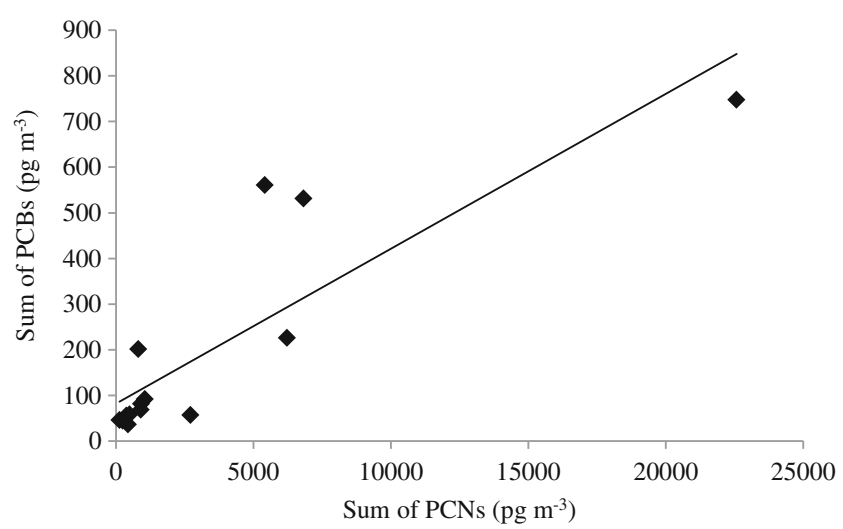

Fig. 5 Correlation between the sum of the tetra-to octa-chlorinated naphthalene concentrations and the sum of the tetra-to octa-chlorinated biphenyl concentrations in the plants studied was recycled and used as a raw material in the sintering process, so fly ash emissions were not included when we calculated the annual emissions of UP-POPs from the converter steelmaking processes. Based on the annual crude steel output in 2012 (at least $5.67 \times 10^{8} \mathrm{t}$ ), our preliminary estimates of the annual atmospheric emissions of PCDD/Fs, PCBs, and PCNs from converter steelmaking through second ventilation systems in China are 30.5, 1.17, and $0.55 \mathrm{~g}$ TEQ, respectively. The National Implementation Plan for the Stockholm Convention on Persistent Organic Pollutants (NIP) of China identified that the total PCDD/F released to the air was $5.0 \mathrm{~kg}$ TEQ years ${ }^{-1}$, about $50 \%$ of which was from ferrous and nonferrous metal production in 2004 (NIP of China 2007). This shows that converter steelmaking processes are probably not a key priority UP-POP source in China.

\section{Conclusions}

The emissions of PCDD/Fs, PCBs, and PCNs from five converter steelmaking plants in China were investigated. Different converter steelmaking processes were studied, and we found that a modern technique (used in plant $\mathrm{C} 1$ ) that causes lower concentrations of common pollutants to be emitted than older techniques do might not actually help to decrease UP-POP emissions. We also found that there was no significant difference in UP-POP emission from different types of converters. We found that the amount of scrap steel included in the converter steelmaking process might influence the UP-POP concentrations emitted, the UP-POP emission concentration increasing as the amount of scrap steel added increased. The amounts of UP-POPs emitted from the converter steelmaking processes were found to be much lower than the amounts emitted from iron ore sintering, electric arc furnaces, and coking processes. This suggests that the converter steelmaking processes are probably not a key priority UP-POP source.

Acknowledgments We gratefully acknowledge support from the National Natural Science Foundation of China (21037003, 21321004, and 21007084), the China Postdoctoral Science Foundation (2013 M540151), and the Chinese Academy of Sciences(YSW2013B01).

\section{References}

Anderson DR, Fisher R (2002) Sources of dioxins in the United Kingdom the steel industry and other sources. Chemosphere 46:371-381

Aries E, Anderson DR, Fisher R, Fray TA, Hemfrey D (2006) PCDD/F and "Dioxin-like" PCB emissions from iron ore sintering plants in the UK. Chemosphere 65:1470-1480

Ba T, Zheng M, Zhang B, Liu W, Su G, Liu G, Xiao K (2010) Estimation and congener-specific characterization of polychlorinated naphthalene emissions from secondary non ferrous metallurgical facilities in China. Environ Sci Technol 44:2441-2446 
Buekens A, Stieglitz L, Hell K, Huang H, Segers P (2001) Dioxins from thermal and metallurgical processes recent studies for the iron and steel industry. Chemosphere 42:729-735

Chiu JC, Shen YH, Li HW, Lin LF, Wang LC, Chang-Chien GP (2011) Emissions of polychlorinated pibenzo-p-dioxins and dibenzofurans from an electric arc furnace, secondary aluminum smelter, crematory and Joss Paper incinerators. Aerosol Air Qual Res 11:13-20

Fisher R, Anderson DR, Pearson SL, Quinn P (1997) Characterisation of releases of polychlorinated dibenzo- $p$-dioxins and dibenzofurans from integrated iron and steelworks in the United Kingdom. Organohalogen Compd 31:261-267

Grochowalski A, Lassen C, Holtzer M, Sadowski M, Hudyma T (2006) Determination of PCDDs, PCDFs, PCBs and HCB emissions from the metallurgical sector in Poland. Environ Sci Pollut Res Int 14: 326-332

Hu J, Zheng M, Nie Z, Liu W, Liu G, Zhang B, Xiao K (2013a) Polychlorinated dibenzo-p-dioxin and dibenzofuran and polychlorinated biphenyl emissions from different smelting stages in secondary copper metallurgy. Chemosphere 90:89-94

Hu J, Zheng M, Liu W, Li C, Nie Z, Liu G, Zhang B, Xiao K, Gao L (2013b) Characterization of polychlorinated naphthalenes in stack gas emissions from waste incinerators. Environ Sci Pollut Res 20: 2905-2911

Jackson K, Aries E, Fisher R, Anderson DR, Parris A (2012) Assessment of exposure to $\mathrm{PCDD} / \mathrm{F}, \mathrm{PCB}$, and $\mathrm{PAH}$ at a basic oxygen steelmaking (BOS) and an iron ore sintering plant in the UK. Ann Occup Hyg 56:37-48

Jager J (1993) PCDD/F and PCB emission from steel producing, processing and reclamation plants with varying input. Toxicol Environ Chem 40:201-211

Liu G, Zheng M, Liu W, Wang C, Zhang B, Gao L, Su G, Xiao K, Lv P (2009) Atmospheric emission of PCDD Fs, PCBs, hexachlorobenzene, and pentachlorobenzene from the coking industry. Environ Sci Technol 43:9196-9201

Liu G, Zheng M, Lv P, Liu W, Wang C, Zhang B, Xiao K (2010) Estimation and characterization of polychlorinated naphthalene emission from coking industries. Environ Sci Technol 44:81568161

Liu G, Zheng M, Du B, Nie Z, Zhang B, Hu J, Xiao K (2012a) Identification and characterization of the atmospheric emission of polychlorinated naphthalenes from electric arc furnaces. Environ Sci Pollut Res Int 19:3645-3650

Liu G, Zheng M, Du B, Nie Z, Zhang B, Liu W, Li C, Hu J (2012b) Atmospheric emission of polychlorinated naphthalenes from iron ore sintering processes. Chemosphere 89:467-472

Lohmann R, Jones KC (1998) Dioxins and furans in air and deposition. A review of levels, behaviour and processes. Sci Total Environ 219: $53-81$

Nie Z, Zheng M, Liu W, Zhang B, Liu G, Su G, Lv P, Xiao K (2011) Estimation and characterization of PCDD/Fs, dl-PCBs, PCNs, $\mathrm{HxCBz}$ and $\mathrm{PeCBz}$ emissions from magnesium metallurgy facilities in China. Chemosphere 85:1707-1712

Nie Z, Liu G, Liu W, Zhang B, Zheng M (2012a) Characterization and quantification of unintentional POP emissions from primary and secondary copper metallurgical processes in China. Atmos Environ 57:109-115

Nie Z, Zheng M, Liu G, Liu W, Lv P, Zhang B, Su G, Gao L, Xiao K (2012b) A preliminary investigation of unintentional POP emissions from thermal wire reclamation at industrial scrap metal recycling parks in China. J Hazard Mater 215-216:259-265

NIP of China (2007) National Implementation Plan for the Stockholm Convention on Persistent Organic Pollutants. http://www.pops.int/ documents/implementation/nips/submissions/China NIP En.pdf>

Noma Y, Yamamoto T, Sakai SI (2004) Congener-specific composition of polychlorinated naphthalenes, coplanar PCBs, dibenzo-p-dioxins, and dibenzofurans in the Halowax Series. Environ Sci Technol 38: $1675-1680$

Sofilic T, Jendricko J, Kovacevic Z, Cosic M (2012) Measurement of polychlorinated dibenzo- $p$-dioxin and dibenzofuran. Arch Metall Mater 57:811-821

Tian B, Huang J, Wang B, Deng S, Yu G (2012) Emission characterization of unintentionally produced persistent organic pollutants from iron ore sintering process in China. Chemosphere 89:409-415

UNEP (2012) Toolkit for identification and quantification of releases of dioxins, furans and other unintentional POPs (under Article 5 of the Stockholm Convention). http:/toolkit.pops.int/Publish/Downloads/ UNEP-POPS-TOOLKIT-2012-En.pdf

Yu Y, Zheng M, Li X, He X (2012) Operating condition influences on $\mathrm{PCDD} / \mathrm{Fs}$ emissions from sinter pot tests with hot flue gas recycling. J Environ Sci 24:875-881 